CZASOPISMO INŻYNIERII LĄDOWEJ, ŚRODOWISKA I ARCHITEKTURY JOURNAL OF CIVIL ENGINEERING, ENVIRONMENT AND ARCHITECTURE

JCEEA, t. XXXII, z. 62 (3/I/15), lipiec-wrzesień 2015, s. 437-445

\author{
Andrzej STUDZIŃSKI ${ }^{1}$ \\ Katarzyna Ida WOŹNIAK ${ }^{2}$
}

\title{
STRATY WYNIKAJĄCE Z BRAKU DOSTAWY WODY W OPINII JEJ KONSUMENTÓW
}

\begin{abstract}
Celem pracy było przeprowadzenie analizy negatywnych skutków braku dostawy wody na podstawie przeprowadzonych wcześniej badań opinii konsumentów. Badania te zrealizowano w oparciu o własnoręcznie stworzoną ankietę. Sondażem objęto 150 respondentów uzyskując opinie dotyczące jakości usług wodociągowych. Ankietowani odpowiadali na pytania z zakresu jakości dostarczanej wody, ciągłości dostawy oraz przerw w dostawie i wynikających $\mathrm{z}$ nich uciążliwości. Głównym zadaniem było określenie wielkości strat finansowych spowodowanych brakiem dostawy wody. Dziewięciu na dziesięciu ankietowanych odczuło niedogodności wynikłe z przerwania dostawy wody w ostatnim roku, głównie w zakresie higieny osobistej oraz przygotowania posiłków. Kobiety mocniej oceniały odczuwane uciążliwości związane z brakiem dostawy wody niż mężczyźni, natomiast osoby powyżej 50-go roku życia ich prawie nie odczuwały. Szacując swoje straty wynikłe z przerw w dostawie wody prawie $90 \%$ osób objętych badaniem oceniło je na mniej niż 50 zł, przy czym ponad połowa ankietowanych uważała, że nie poniosła strat. $2 / 3$ badanych uważała, że przerwy w dostawie wody są naturalne i nie oczekuje finansowego zadośćuczynienia od dostawcy wody za poniesione straty. Płeć oraz wiek nie ma związku z opinią dotyczącą rekompensaty za straty finansowe spowodowane przerwą w dostawie wody, natomiast im wyższe wykształcenie respondentów, tym więcej osób uważało, iż należy im się zadośćuczynienie za wynikłą stratę finansową spowodowaną przerwą w dostawie wody.
\end{abstract}

Słowa kluczowe: ryzyko, zaopatrzenie w wodę, badania konsumenckie, awaria

\section{Wprowadzenie}

Dotychczasowe badania ryzyka wynikającego z awarii systemów zaopatrzenia $\mathrm{w}$ wodę skupiają się na skutkach tych awarii dla ciągłości dostawy wody i jej bezpieczeństwa. Pierwszy z aspektów odnoszony jest do dostawcy wody [13, 15-20, 22-24], drugi koncentruje się na konsumencie wody [12, 14, 16, 17, 21]. Straty wynikające $\mathrm{z}$ awarii przewodów wodociągowych są skatalogowane [13, 23], skutki najczęściej opisuje się wskaźnikami [23]. Ciekawe wydaje się

\footnotetext{
${ }^{1}$ Autor do korespondencji/corresponding author: Andrzej Studziński, Politechnika Rzeszowska, Al. Powstańców Warszawy 6, 36-959 Rzeszów, tel. 178521703, astud@ prz.edu.pl

${ }^{2}$ Katarzyna Ida Woźniak, Politechnika Rzeszowska
} 
przedstawienie strat wynikających z przerw w ciągłości dostawy wody w ujęciu finansowym w ocenie konsumenta [25, 26]. Zagadnienie to stanowi cel niniejszego opracowania, który zrealizowano w oparciu o ankietowe badania konsumenckie.

\section{Metodyka badań}

W badaniach konsumenckich dotyczących wodociągów wykorzystuje się niektóre instrumenty konwencjonalne [1, 2, 4, 5, 9]. Należą do nich: wywiad bezpośredni, wywiad telefoniczny, wywiad zogniskowany (dyskusje grupowe), ankiety pocztowe i do samodzielnego uzupełniania oraz badania internetowe. Zaletą pierwszej z wymienionych metod jest bezpośredni kontakt $\mathrm{z}$ respondentem, co przekłada się na precyzyjność wyjaśnień. Podczas badania prowadzonego przy użyciu wywiadu bezpośredniego ankietowany ma więcej czasu niż w przypadku wykorzystania innych technik, aby zastanowić się nad odpowiedzią. Także ankieter ma czas na to, aby upewnić się, że dobrze zrozumiał drugą stronę. Kolejną zaletą jest dogłębność wywiadu. W tej metodzie ankieter ma okazję do kontrolowania przebiegu rozmowy. Zazwyczaj liczba pytań pozostawionych bez odpowiedzi jest bardzo znikoma lub zerowa. Do wad tej metody można zaliczyć reprezentatywność próby. Badania takie prowadzone są zazwyczaj w jednym mieście, rejonie, co może przekładać się na małe zróżnicowanie ankietowanych [3, 6, 7].

Badanie zostało przeprowadzone na losowo wybranych respondentach, badanie było anonimowe, zostało przeprowadzone w dniach 15 - 30 marca 2015 r. Przeprowadzono 175 ankiet, lecz z powodu błędnie wypełnionych ankiet lub braku odpowiedzi na większość pytań, 15 ankiet odrzucono. We właściwym badaniu wzięło więc udział 150 respondentów. Należy uwzględnić fakt marginesu błędu, który przy założonym poziomie ufności $95 \%$ wynosi $8 \%$ dla wielkości próby badawczej równej 150 osób [7].

Dokonano przeglądu literatury $[8,10,11,27]$ oraz dotychczasowych badań i stworzono ankietę składającą się z 27 pytań: 5 pytań metryczkowych oraz 23 pytań merytorycznych. W ankiecie znalazły się pytania tak zwane filtrujące, badające czy respondenci są zaopatrzeni w wodę wodociągową oraz czy doświadczyli przerwy w dostawie wody w przeciągu ostatniego roku. Po udzieleniu pozytywnej odpowiedzi na dwa wyżej wymienione pytania, ankietowani odpowiadali na bardziej szczegółowe pytania. Pytania te można podzielić na zamknięte jednokrotnego lub wielokrotnego wyboru (24 pytania) oraz otwarte (4 pytania).

W pytaniach metryczkowych ankietowani określali: płeć, wiek, wykształcenie, średnie dochody oraz wielkość jednostki osadniczej, w której zamieszkują. Następnie odpowiadali na pytania dotyczące zaopatrzenia w wodę ( $\mathrm{z}$ wodociągu czy indywidualnie), wysokości opłat za wodę, przerw w dostawie wody. Ostatnie pytania (21-27) dotyczyły oceny uciążliwości wynikających z przerw w dostawie wody, przedstawiono je poniżej: 
21. Czy odczuł/a Pan/i uciążliwości/niedogodności związane z przerwą w dostawie wody?

○ Tak

○ Nie

22. Czego dotyczyły uciążliwości/niedogodności wynikające z przerwy w dostawie wody? (proszę zaznaczyć maksymalnie 3 odpowiedzi)

$\circ$ Higieny osobistej

- Zmywania naczyń

- Sprzątania/utrzymania porządku

- Prania

- Przygotowania posiłków

- Utrzymania roślin/zieleńców/ogródków

○ Dotyczące zwierząt

○ Inne

23. Na ile ocenia Pan/i straty finansowe wynikające $\mathrm{z}$ przerwy w dostawie wody? (proszę podać kwotę)

................ zł

24. Czy uważa Pan/i, że dostawca wody powinien zadośćuczynić wynikłej straty finansowej?

○ Tak

○ Nie

25. Jeżeli uważa Pan/i, że dostawca wody powinien zadośćuczynić wynikłej straty finansowej, to jak wysokie powinno ono być? (proszę podać kwotę)

............... zł

26. Czy zgodziłby/zgodziłaby się Pan/i płacić większe rachunki za wodę w zamian za zredukowanie liczby przerw w dostawie wody?

○ Tak

○ Nie

27. Jeżeli zgodziłby/zgodziłaby się Pan/i płacić większe rachunki za wodę w zamian za zredukowanie liczby przerw w dostawie wody, to o ile więcej mogłyby wzrosnąć te rachunki? (proszę podać kwotę) zł.

\section{Wyniki badań}

Kobiety stanowiły 55\% wszystkich badanych, natomiast mężczyźni $45 \%$. Ankietowanych podzielono na sześć grup wiekowych: 18 - 25, 26 - 35, 36 - 50, 51 - 65, 66 -. Najliczniejszą grupę stanowiły osoby w wieku od 18 do 25 lat (77\%), natomiast najmniej liczną osoby pomiędzy 65, a 75 rokiem życia, to tylko $1 \%$. Można zauważyć, że wraz ze wzrostem wieku maleje liczba respondentów. Najliczniejszą grupę stanowią osoby z wykształceniem średnim (56\%). Związane jest to $\mathrm{z}$ wiekiem respondentów, ponieważ największą grupę stanowiły osoby do 25 roku życia, aż $77 \%$. Drugą, co do wielkości grupą są osoby o wykształceniu 
wyższym (40\%). Osoby z wykształceniem podstawowym oraz zawodowym, stanowią po $2 \%$ (po 3 osoby). Prawie połowa respondentów $(47,3 \%$ ) to osoby mieszkające w miejscu, gdzie liczba ludności jest mniejsza niż 5 tysięcy osób, natomiast ćwierć badanych $(24,7 \%)$ to osoby mieszkające w miejscu, gdzie liczba ludności wynosi od 5 do 50 tysięcy osób. W sumie $72 \%$ respondentów mieszka w miejscu o liczbie ludności do 50 tysięcy osób. Rozkład dochodów na członka rodziny w poszczególnych grupach jest podobny. $67,3 \%$ badanych znajduje się w grupie dochodów pomiędzy 500 a 2000 zł na członka rodziny netto (33,3\% - 500 - 1 000zł, $34,0 \%$ - $1000-2000 \mathrm{zł}) .14,7 \%$ stanowią osoby o dochodach poniżej $500 \mathrm{zł}$ na osobę, natomiast $17,3 \%$ to osoby o dochodach powyżej 2000 zł. Dwie skrajne grupy dochodów (<500 zł oraz > 2000 zł) mają bardzo zbliżoną ilość respondentów (22 oraz 26 osób), tak samo jak dwie środkowe grupy dochodów (500 do 1000 zł - 50 osób oraz 1000 do 2000 zł - 51 osób).

Prawie $2 / 3$ badanych jest zaopatrzonych w wodę z wodociągów komunalnych (66\%). 34\% osób ciągle nie ma dostępu do wody wodociągowej. Spośród osób zaopatrzonych w wodociąg zdecydowana większość doświadczyła przerwy w dostawie wody w ostatnim roku (83\%), natomiast w przypadku osób zaopatrzonych ze źródeł indywidualnych naczelną grupą są osoby, które nie doświadczyły takiej przerwy (69\%). W przypadku zaopatrzenia w wodę wodociągową, najliczniejszą grupę stanowią osoby, które doświadczyły tylko jednej przerwy w dostawie wody w przeciągu ostatniego roku, stanowią one $45 \%$ zaopatrywanych z wodociągów, a $38 \%$ ogółu. Aż 6,5\% miało do czynienia co najmniej $\mathrm{z}$ pięcioma przerwami.

Ponad 2/3 badanych doświadczyło przerw trwających w godzinach pracy $(6: 00 \div 14: 00)$. Przypuszczalnie przerwa ta nie była zbyt uciążliwa dla nich, oczywiście jeżeli pracują w tych godzinach. $21 \%$ ankietowanych odnotowało przerwy pomiędzy 14:00 a 21:00.

Odnosząc się do osób zaopatrzonych w wodę wodociągową, aż 93\% badanych zostało wcześniej poinformowanych o zamierzonej przerwie w dostawie wody. Aż u 59\% badanych przerwa w dostawie wody była krótsza niż wcześniej zapowiadano. $32 \%$ osób wskazało na dłuższą przerwę, a u $9 \%$ odbyła się ona $\mathrm{w}$ innym terminie.

W obu przypadkach zaopatrzenia w wodę wodociągową najwięcej osób mieści się w grupie, której czas przerwy nie przekroczył 6 godzin. Tak samo w obu przypadkach nie ma ani jednej osoby, która doświadczyłaby przerwy w dostawie wody, która trwała od 4 do 7 dni. Największa grupa spośród osób zaopatrzonych w wodociąg (57\%) to osoby nieposiadające dostępu do wody w okresie nieprzekraczającym 6 godzin. Przerwy od 6 do 12 h - doświadczyło $28 \%$ ogółu respondentów. Znalazły się także 3 osoby (4\%), które nie miały dostępu do wody wodociągowej aż przez okres co najmniej 7 dni. Można podejrzewać, że było to następstwem bardzo poważnej awarii wodociągowej. Uogólniając można stwierdzić, że wraz ze wzrostem długości trwania przerwy braku dostawy wody maleje ilość osób, które ją doświadczyły. 
Zasadnicza grupa to osoby, które nie znają wielkości kwoty płaconej za zużytą wodę $(28,3 \%)$. Dwa kolejne miejsca przedziału kwotowego opłat różnią się jedynie $1 \%$. Najwięcej osób (20,2\%) płaci rachunki w wysokości 101 do 150 zł za miesiąc. Kolejne miejsce to grupa odbiorców $(19,2 \%)$ płacących od 50 do 100 zł. Z najwyższymi rachunkami, bo powyżej 200 zł zmaga się jedynie 5,1\% ogółu ankietowanych, natomiast z najniższymi (poniżej $50 \mathrm{zł}$ ) 13,1\%. W środku stawki $(14,1 \%)$ znajdują się osoby płacące rachunki w wysokości od 151 do $200 \mathrm{zl}$.

Znaczna większość, bo aż 89\% badanych odczuło uciążliwości związane z brakiem dostawy wody. Jedynie $11 \%$ nie stwierdziło takiej dokuczliwości. W trzech zakresach wiekowych (18 - 25 lat, 26 - 35 lat, 36 - 50 lat) na pierwszym miejscu znalazła się higiena osobista z wynikami odpowiednio: 32,2\%, $32,4 \%$ i 33,3\%. Wśród osób pomiędzy 51 a 65 rokiem życia jako największe uciążliwości wskazano na czynności związane z przygotowywaniem posiłków $37,5 \%$. Ten rodzaj niedogodności znalazł się na drugim miejscu w kategorii wiekowej 26 - 35 lat $(23,5 \%)$ oraz 36 - 50 lat $(28,6 \%)$.

Zakres strat finansowych przyjętych do analizy zawierał się w granicach od 0 do 200 zł. Aż 53,7\% badanych nie stwierdziło jakichkolwiek strat finansowych (0 zł). Niektórzy z nich (około 5\%) twierdzą, że brak dostawy wody oznacza dla nich „zysk”, gdyż nie zużywają wody, więc za nią nie zapłacą. Drugą co do wielkości była grupa wyceniająca straty na $50 \mathrm{zł}-13,4 \%$. Straty podzielono na 3 przedziały: $1-50$ zł, $51-100$ zł, $101-200$ zł. 33\% ankietowanych oceniło straty na najniższym poziomie ( 1 - 50 zł), blisko $5 \%$ zdecydowało się na środkowy zakres (51 - $100 \mathrm{zł})$, a 4\% na najwyższy (101 - $200 \mathrm{zł})$. W przybliżeniu 5\% osób nie udzieliło odpowiedzi na pytanie. Stwierdzono na podstawie powyższych wyników, że większość osób (87\%) wycenia straty finansowe na najniższym poziomie (do $50 \mathrm{zł})$ lub ich nie odczuwa (0 zł).

Ponad połowa osób (57\%) w wieku od 18 do 25 lat nie odczuła żadnych strat finansowych $(0 \mathrm{zł})$. Straty wynoszące od 1 do 50 zł oceniło $29 \%$ osób najmłodszych i $46 \%$ osób w wieku od 26 do 35 lat. Osoby w wieku od 36 do 50 lat nie odczuły start finansowych (0 zł) lub wyceniły je w przedziale od 1 do 50 zł. Generalizując można stwierdzić, że ponad połowa badanych w wieku od 18 do 25 lat $(57 \%)$ nie odczuwa strat finansowych, prawie połowa osób w przedziale wiekowym od 26 do 35 lat (46\%) takie straty ocenia na poziomie od 1 do $50 \mathrm{zl}$, aż ponad $90 \%$ badanych wycenia straty finansowe w przedziale od 1 do $100 \mathrm{zl}$, a tylko niecałe $10 \%$ w kwocie od 101 do 200 zł. Najliczniejsza grupa oceniająca straty finansowe na 0 zł to ci, których dochody na członka rodziny nie przekraczają 500 zł. Prawie $1 / 4$ badanych, która poniesiony ubytek pieniężny określiła w granicach od 1 do $50 \mathrm{zł}$ to respondenci o zarobkach w przeliczeniu na członka rodziny od 500 do $1000 \mathrm{zł}-23,8 \%$, ale to także ci o niższych dochodach (nieprzekraczających 500 zł) - 23,0\%. Generalizując można stwierdzić, że im wyższe posiadane dochody, tym kwota ocenianej straty finansowej jest większa. 
Średnia wartość straty finansowej w ocenie respondentów wynosi 43,89 zł dla osób mających wodociąg, natomiast dla wszystkich badanych to 28,56 zł. Średnie straty finansowe spowodowane jedną przerwą braku dostawy wody wynoszą $21,28 \mathrm{zł}$ w przypadku wszystkich ankietowanych, natomiast 25,27 zł dla tych, którzy są zaopatrzeni w wodociąg.

$67 \%$ badanych uważa, że dostawca nie powinien zadośćuczynić wynikłej straty finansowej. Odmiennego zdania jest $28 \%$ respondentów. $5 \%$ nie udzieliło odpowiedzi na to pytanie, wszystkie osoby, które wyceniły straty finansowe na 0 zł (44\%) znalazły się w grupie, która nie domaga się rekompensaty. Spośród osób, które uważają, że należy im się rekompensata niemalże połowa (43\%) domaga się kwoty do 50 zł. 35\% żąda większej sumy pieniędzy od 51 do 100 zł włącznie. Znalazła się także jedna osoba, która stwierdziła, iż zadośćuczynienie powinno wynosić w granicach od 450 do 500 zł.

Zdecydowana większość (82\%) nie zgodziłaby się płacić wyższych rachunków za wodę w zamian za zredukowanie liczby przerw w jej dostawie. Na wyniki te nie ma wpływu płeć, wiek, wykształcenie, miejsce zamieszkania oraz wysokość rachunków badanych. Wraz ze wzrostem dochodów rośnie liczba osób wyrażających zgodę na wyższe opłaty za wodę w zamian za zredukowanie liczby przerw w jej dostawie.

Wśród tych, którzy gotowi są ponosić wyższe koszty za zwiększenie niezawodności dostawy wody, większość osób, bo aż $67 \%$ zgodzi się na płacenie wyższych rachunków pod warunkiem, że nie wzrosną o więcej niż 20 zł. Blisko 90\% ankietowanych podało kwotę podwyższenia rachunków nieprzekraczającą 50 zł. Ludzie starsi oraz osoby z wyższym wykształceniem godzą się płacić wyższe rachunki w zamian za zredukowanie liczby przerw w dostawie wody. Im wyższe dochody badanych tym rośnie możliwa kwota zwiększenia opłat za zużycie wody w zamian za zredukowanie liczby przerw w jej dostawie, natomiast im wyższe dotychczasowe rachunki za zużycie wody, tym mniejsze przyzwolenie na płacenie wysokich kwot za zredukowanie liczby przerw w jej dostawie.

\section{Wnioski}

1. Przeprowadzone badania wykazały, że większe ryzyko braku dostawy wody występuje w przypadku zaopatrzenia w wodociąg komunalny (83\%), niż w sytuacji jego braku (31\%). 65\% badanych doświadczyło przerwy w dostawie wody, w przeciągu ostatniego roku, a prawie połowa osób zaopatrzonych $\mathrm{w}$ wodę wodociągową zmagało się tylko $\mathrm{z}$ jedną przerwą. Dodatkowo można stwierdzić, że wraz ze wzrostem liczby przerw w dostawie wody maleje ilość osób, które je doświadczyły.

2. Znaczna większość, bo aż $89 \%$ badanych odczuło uciążliwości związane z brakiem dostawy wody. Większość niedogodności (77\%) dotyczy codziennych czynności takich jak gotowanie, zmywanie naczyń i higiena osobista. Więcej kobiet niż mężczyzn zaznała problemów przy sprzątaniu 
w sytuacji braku dostawy wody, a mężczyźni wskazali na niewygody związane z utrzymaniem zieleni. Dodatkowo we wszystkich kategoriach wiekowych największe problemy przy braku dostawy wody związane są $\mathrm{z}$ higieną osobistą. Wyjątek stanowi kategoria wiekowa od 51 do 65 lat, gdzie największa uciążliwość związana jest $\mathrm{z}$ przygotowywaniem posiłków. W najmniejszych osadach, czy też miasteczkach (poniżej 5 tysięcy osób) nikt nie odczuwa uciążliwości związanych z utrzymaniem roślin, ogródków. Przyczyną takiej odpowiedzi badanych $w$ tej grupie może być ich dostęp do innego źródła wody niż wodociąg i z niego korzystają przy podlewaniu zieleńców. Można stwierdzić, że wykształcenie nie ma wpływu na rodzaj odczuwanych uciążliwości, a kobiety mocniej oceniają odczuwane uciążliwości związane z brakiem dostawy wody niż mężczyźni, natomiast osoby powyżej 50-go roku życia ich prawie nie odczuwają.

3. Zdecydowana większość osób (87\%) wycenia straty finansowe na najniższym poziomie (do $50 \mathrm{zł}$ ) lub ich nie odczuwa (54\%). Poziom wykształcenia nie ma wpływu na wysokość odczuwanych strat finansowych, jednak im wyższe posiadane dochody, tym kwota ocenianej straty finansowej jest większa.

4. 2/3 badanych nie wymaga finansowego zadośćuczynienia od dostawcy wody za poniesione straty $\mathrm{w}$ wyniku przerw $\mathrm{w}$ jej dostawie. Niezależnie od wielkości miasta większość osób uważa, że dostawca nie powinien rekompensować im wynikłej straty finansowej za przerwę w dostawie wody. Wyjątkiem są osoby mieszkające w aglomeracjach od 50 do 100 tysięcy osób, gdzie większość sądzi, iż należy im się zadośćuczynienie. Płeć oraz wiek nie ma związku z opinią dotyczącą rekompensaty za straty finansowe spowodowane przerwą $\mathrm{w}$ dostawie wody, natomiast im wyższe wykształcenie respondentów, tym więcej osób uważa, że należy im się zadośćuczynienie za wynikłą stratę finansową spowodowaną przerwą w dostawie wody. Charakterystycznym wynikiem jest fakt, że im wyższy dochód netto na członka rodziny, tym mniejszy odsetek żądających rekompensaty za straty finansowe związane z brakiem dostawy wody.

\section{Literatura}

[1] Churchill G. A.: Badania marketingowe. Podstawy metodologiczne. Wydawnictwo Naukowe PWN, Warszawa 2002.

[2] Goodyear M.: Qualitative research. ESOMAR, London 1998.

[3] Hague P.: Badania marketingowe. Planowanie, metodologia i ocena wyników. Wydawnictwo HELION, Gliwice 2006.

[4] Hague P., Jackson P.: Badania rynku, zrób to sam. Wydawnictwo Znak - Signum, 1992.

[5] Higgins C. A., Dimnik T. P., Greenwood H. P., The DISKQ Survey Method. Journal of the Market Research Society, 1987, p. 437-445. 
[6] Kaczmarczyk S.: Badania marketingowe. Metody i techniki. Polskie Wydawnictwo Ekonomiczne, wydanie trzecie zmienione, Warszawa 2003.

[7] Kaden R. J.: Badania marketingowe. Polskie Wydawnictwo Ekonomiczne, Warszawa 2008.

[8] Kieżel E.: Konsument i jego zachowania na rynku europejskim. Polskie Wydawnictwo Ekonomiczne, Warszawa 2010.

[9] Kramer J.: Badania rynkowe i marketingowe. Polskie Wydawnictwo Ekonomiczne, Warszawa 1994.

[10] Pietrucha-Urbanik K.: Badanie użytkowników wodociągów publicznych na temat przerw w dostawie wody. Materiały Konferencyjne "Przedsiębiorstwa wodociągowo-kanalizacyjne w dobie współczesnych problemów", Wydawnictwo AQUA S.A. Bielsko-Biała, Szczyrk 2009, p. 71-84.

[11] Pietrucha-Urbanik K.: Prioritizing water pipe renewal using fuzzy set theory, Journal of KONBiN 1(33)2015, s. 243-250. DOI 10.1515/jok-2015-032.

[12] Rak J.: Bezpieczna woda wodociągowa. Zarządzanie ryzykiem w systemie zaopatrzenia w wodę. Oficyna Wydawnicza Politechniki Rzeszowskiej, Rzeszów 2009.

[13] Rak J.: Istota ryzyka w funkcjonowaniu systemu zaopatrzenia w wodę. Oficyna Wydawnicza Politechniki Rzeszowskiej, Rzeszów 2004.

[14] Rak J.: Podstawy bezpieczeństwa systemów zaopatrzenia w wodę. Komitet Inżynierii Środowiska PAN, Lublin 2005.

[15] Rak J.: Problematyka ryzyka w wodociągach. Oficyna Wydawnicza Politechniki Rzeszowskiej, Rzeszów 2014.

[16] Rak J. i inni: Metody oceny niezawodności i bezpieczeństwa dostawy wody do odbiorców. Oficyna Wydawnicza Politechniki Rzeszowskiej, Rzeszów 2013.

[17] Rak J. i inni: Niezawodność i bezpieczeństwo systemów zbiorowego zaopatrzenia w wodę. Oficyna Wydawnicza Politechniki Rzeszowskiej, Rzeszów 2012.

[18] Rak J., Tchórzewska-Cieślak B.: Czynniki ryzyka w eksploatacji systemów zaopatrzenia w wodę. Oficyna Wydawnicza Politechniki Rzeszowskiej, Rzeszów 2007.

[19] Rak J., Tchórzewska-Cieślak B.: Metody analizy i oceny ryzyka w systemie zaopatrzenia w wodę. Oficyna Wydawnicza Politechniki Rzeszowskiej, Rzeszów 2005.

[20] Rak J., Tchórzewska-Cieślak B.: Ryzyko w eksploatacji systemów zbiorowego zaopatrzenia w wodę. Wydawnictwo Seidel-Przywecki Sp. z o.o., 2013.

[21] Rak J., Tchórzewska-Cieślak B., Studziński J.: Bezpieczeństwo systemów zbiorowego zaopatrzenia w wodę. Instytut Badań Systemowych PAN, Warszawa 2013.

[22] Studziński A., Kobylarz J.: Jakościowa analiza ryzyka awarii przewodów wodociągowych wodociągu grupowego. Czasopismo Inżynierii Lądowej, Środowiska i Architektury, t. XXXI, z. 61 (1/14), 2014, p. 311-321.

[23] Tchórzewska-Cieślak B.: Metody analizy i oceny ryzyka awarii podsystemu dystrybucji wody. Oficyna Wydawnicza Politechniki Rzeszowskiej, Rzeszów 2011.

[24] Tchórzewska-Cieślak B., Pietrucha-Urbanik K.: Eksploatacja SZZW w aspekcie przynależności do infrastruktury krytycznej. Journal of KONBiN nr 2 (26), 2013, p. 165-172.

[25] Tchórzewska-Cieślak B., Pietrucha-Urbanik K.: Poziomy nienaruszalności bezpieczeństwa w systemach zbiorowego zaopatrzenia w wodę. Instal 12, 2014, s. 109-112. 
[26] Tchórzewska-Cieślak B., Pietrucha-Urbanik K., Bajer J.: Crisis situation management issues in urban areas water supply, Journal of Polish Safety and Reliability Association, Summer Safety and Reliability Seminars, vol. 6, no 2, 2015, pp. 135-146.

[27] Żurowski M., Odpowiedzialność przedsiębiorstwa wodociągowo-kanalizacyjnego z tytułu nienależytego wykonania umowy o zaopatrzenie w wodę. Przegląd Prawa Ochrony Środowiska nr 4, 2013, p. 31-58.

\section{LOSSES RESULTING FROM THE LACK OF SUPPLY OF WATER IN THE OPINION OF THE CONSUMERS}

\section{S u m m a r y}

The aim of the study was to analyze the negative effects of the lack of water supply on the basis of investigations carried out by the consumer. This research was carried out on the basis of personally created the survey. Survey covered 150 respondents to obtain opinions on the quality of water services. The respondents' answered to questions concerning the quality of the water supply, continuity of supply and outages and resulting inconvenience. The main task was to determine the size of the financial loss caused by lack of water supply. Nine out of ten respondents felt the inconvenience caused by interruption of water supply in the last year, mainly in the field of personal care and meal preparation. Women felt more strongly evaluated the nuisance associated with lack of water supply than men, while those above 50 years of age are almost not felt. Estimating their losses resulting from interruptions in water supply almost $90 \%$ of those surveyed rated it at less than $50 \mathrm{zl}$, with more than half of those surveyed thought that did not incur any losses. 2/3 of the respondents believed that water outages are natural and do not expect financial compensation from the supplier of water for their losses. Gender and age has no connection with the opinion on compensation for financial losses due to interruption in the supply of water, and the higher the education of the respondents, the more people felt that they deserve compensation for the financial loss sustained due to the interruption of water.

Keywords: risk, water supply, consumer research, failure

Przestano do redakcji: $30.05 .2015 \mathrm{r}$.

Przyjęto do druku: 30.10 .2015 r.

DOI: $10.7862 / \mathrm{rb} .2015 .127$ 